\title{
Influence of liver cancer on lipid and lipoprotein metabolism Jingting Jiang ${ }^{1,2}$, Peter Nilsson-Ehle ${ }^{1}$ and Ning $\mathrm{Xu}^{* 1}$
}

\begin{abstract}
Address: ${ }^{1}$ Section of Clinical Chemistry \& Pharmacology, Institute of Laboratory Medicine. Lund University, S-221 85 Lund, Sweden and ${ }^{2}$ Department of Tumor Biological Treatment, The Third Affiliated Hospital, Su Zhou University, Changzhou 213003, China

Email: Jingting Jiang - jingtingjiang@yahoo.com.cn; Peter Nilsson-Ehle - Peter.nilsson-ehle@med.lu.se; Ning Xu* - ning.xu@med.lu.se

* Corresponding author
\end{abstract}

Published: 03 March 2006

Lipids in Health and Disease2006, 5:4 doi:10.1 186/1476-5IIX-5-4

This article is available from: http://www.lipidworld.com/content/5/l/4

(c) 2006jiang et al; licensee BioMed Central Ltd.

This is an Open Access article distributed under the terms of the Creative Commons Attribution License (http://creativecommons.org/licenses/by/2.0), which permits unrestricted use, distribution, and reproduction in any medium, provided the original work is properly cited.
Received: 02 December 2005

Accepted: 03 March 2006

\begin{abstract}
Liver plays a key role in the metabolism of plasma apolipoproteins, endogenous lipids and lipoproteins. Hepatocellular carcinoma (HCC) is one of the most common fatal malignant tumors in China and in other Southeast Asian countries. This has been attributed to the high incidence of hepatitis B infection. Hepatitis B proteins, such as the hepatitis B $X$ protein $(\mathrm{HBx})$ that is large hepatitis $B$ surface protein could regulate transcription of many candidate genes for liver carcinogenesis. It has known that patients who suffered from acute hepatitis B could have lipid disorders such as decreased plasma level of high-density lipoproteins (HDL). Furthermore, aberrations of lipid metabolism are often seen in the chronic hepatitis $B$ infection.

Plasma lipid profiles could be changed under HCC. In majority of the reports in HCC, plasma levels of triglycerides (TG), cholesterol, free fatty acids (FFA), HDL, low-density lipoproteins (LDL), lipoprotein (a) (Lp(a)), apolipoprotein Al (apoAl) and apoB were slight to significantly decreased, however, in some cases plasma levels of TG and $L p(a)$ might be increased. It has been suggested that analysis of plasma levels of lipids, lipoproteins and apolipoproteins in the patients suffered from $\mathrm{HCC}$ reflects on the hepatic cellular impairment status. Studies revealed that alterations seen in the plasma levels of lipids, lipoproteins and apolipoproteins reflecting patients' pathologic conditions. Decreased serum levels of cholesterol and apoAl may indicate a poor prognosis.

Human leukaemic cells and certain tumor tissues have a higher receptor-mediated uptake of HDL and LDL than the corresponding normal cells or tissues. LDL and HDL have therefore been proposed as a carrier for the water-insoluble anti-cancer agents.
\end{abstract}

\section{Introduction}

Liver is one of the most important organs in energy metabolism. Most plasma apolipoproteins, endogenous lipids and lipoproteins are synthesized in the liver [1,2], which depends on the integrity of cellular functions of liver [2,3]. Under normal physiological conditions, liver ensures homeostasis of lipid and lipoprotein metabolism [4]. Hepatic cellular damage and HCC impairs these processes, leading to alterations in plasma lipid and lipopro- tein patterns. Mortality due to liver cancer is the fifth common malignant tumor worldwide [5], and it is closely related to the infections of hepatitis B virus (HBV) [6-8] and hepatitis $\mathrm{C}$ virus (HCV) [9]. HBV proteins, such as the hepatitis B X protein ( $\mathrm{HBx}$ ) that is large hepatitis B surface protein could regulate transcription of many candidate genes for liver carcinogenesis [10,11]. As HBV and HCV infections are quite common in China and in other Southeast Asian countries [12-14], the mortality of HCC is 20,4/ 
Table I: Summarization of serum lipid/lipoprotein changes under HCC

\begin{tabular}{|c|c|c|}
\hline Lipids/Lipoproteins & Changes under liver cancer & References \\
\hline Triglycerides & $\begin{array}{c}\uparrow \\
\downarrow \downarrow \text { or- }\end{array}$ & $\begin{array}{l}{[26]} \\
{[21],[22]}\end{array}$ \\
\hline Total cholesterol & $\begin{array}{c}\uparrow \\
\downarrow \text { to } \downarrow \downarrow\end{array}$ & $\begin{array}{l}{[26]} \\
{[19],[21],[22],[36]}\end{array}$ \\
\hline Free fatty acids & $\uparrow$ & {$[52]$} \\
\hline Lp(a) & $\begin{array}{c}\uparrow \\
\downarrow \text { to } \downarrow \downarrow\end{array}$ & $\begin{array}{l}{[75]} \\
{[21],[72],[73]}\end{array}$ \\
\hline HDL & $\downarrow \downarrow$ & {$[19],[21],[22],[36],[79]$} \\
\hline LDL & $\downarrow$ & {$[19]$} \\
\hline ApoAl & 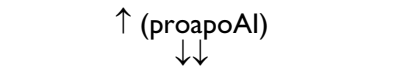 & {$\left[\begin{array}{l}{[19],[24],[23],[82]}\end{array}\right.$} \\
\hline ApoAll & $\downarrow \downarrow$ & [24], [23] \\
\hline ApoB & $\downarrow$ & [83] \\
\hline ApoM & $\downarrow \downarrow$ Hepatic expression & Unpublished data \\
\hline
\end{tabular}

$\uparrow$ slight increase; $\uparrow$ slight decrease; $\downarrow \downarrow$ significant decrease; - no change.

100,000 in the population of China, corresponding to about $18.8 \%$ of all fatal malignant tumors [12]. Hepatic diseases differ from most other causes of secondary dyslipidemia in that the circulating lipoproteins are not only present in abnormal amounts but they frequently also have abnormal composition, electrophoretic mobility and appearance [15]. It has been demonstrated that patients suffered from acute hepatitis B could have lipid disorders, for instance, decreased plasma HDL $[16,17]$. The aberrations of lipid metabolism are often seen in the chronic hepatitis B infection too [18]. HDL and its major apolipoproteins, apoAI and apoAII, are frequently reduced in the patients suffered from cirrhosis or HCC [15]. Decrease in the level of serum LDL cholesterol in patients with liver disease was significantly correlated to the increasing severity of the disease [19-22]. In the present review we discussed aberrations of lipid profiles in the patients suffered from HCC. Decreased serum levels of cholesterol and apoAI may indicate a poor prognosis [22$24]$. The changes of lipid profiles under HCC are listed in table 1 .

\section{Influence of HCC on metabolism of triglycerides, cholesterol and free fatty acids}

The patients with HCC frequently have other liver diseases such as chronic hepatitis and cirrhosis. All these conditions (hepatitis and cirrhosis of the liver) are often associated with plasma lipid and lipoprotein aberrations [25]. It has been demonstrated that plasma triglycerides (TG) decreased by $20-30 \%$ in the patients with HCC [21]. In contrast, Alsabti [26] reported that serum TG in HCC patients were increased when compared to those with cirrhosis. Ooi, et al., [22] reported that plasma TG levels in HCC patients were not significantly different compared with controls. These results emphasize the fact that changes of plasma lipid profile may not always imply the presence of HCC and one need to exercise caution in interpreting these results.

It is known that lipids and lipoprotein metabolism could be regulated by cytokines. For instance, interleukin-6 (IL$6)$, tumor necrosis factor (TNF- $\alpha$ ), IL-1 may inhibit TG synthesis [27]. Tumor cells are known to produce large amounts of pro-inflammatory cytokines that, in turn, may suppress plasma TG levels. Argiles, et al., reported that IL1 profoundly affects lipid metabolism by delaying intestinal absorption and decreasing tissue uptake [28]. IL-2 could induce severe hypocholesterolemia that is mediated by the inhibition of lecithin:cholesteryl acyltransferase (LCAT) activity [29]. IL-1 and IL-6 significantly decreased microsomal triglyceride transfer protein (MTP) mRNA levels in HepG2 cells [30]. It is believed that MTP is related to the synthesis of very low density lipoprotein (VLDL) [31]. In addition, these cytokines could also decrease lipolysis in vivo [32]. Similar results have been reported in other types of cancers [33].

About $80 \%$ endogenous cholesterol are synthesized in the hepatocellular microsomes that contain cholesterol synthesis enzymes [34,35]. In HCC and chronic liver diseases the synthesis and metabolism of cholesterol are impaired. It leads to a decrease in plasma cholesterol levels $[19,21,22,36]$. Li reported [37], in a forward investigation, the relationship between serum cholesterol and occurrence of cancers in 9021 employees aged from 35 to 64 years old. No evidence of association of serum cholesterol level with total cancer mortality was seen by Log-rank trend test. But there was a significant negative correlation between serum cholesterol level and HCC $(\mathrm{P}<0.05)$. This negative correlation also existed between serum cholesterol level and chronic hepatitis and liver cirrhosis. Similar results were described in patients with gastrointestinal 
cancer, however, lower cholesterol levels are not related to the cancer stages [38]. Decreased serum cholesterol concentrations were also found in other cancers [39-41], which are probably related to the increased consumption of cholesterol by the tumor cells, as cholesterol levels in the hepatoma tissues were doubled compared to the control tissues [42]. In addition, it has been reported that synthesis of cholesterol is reduced under cancers [43], and moderate increases of serum cholesterol levels and increased body mass index (BMI) may have a protective effect on cancer mortality $[44,45]$. It was observed that the plasma HDL-cholesterol was inversely correlated to the cholesterol levels in the tumor tissues in cancer patients [46]. Because the use and storage of cholesterol are increased within the tumor tissues during growth, it is possible to hypothesize that lower HDL levels observed in patients with gastrointestinal cancer are associated with the increased cholesterol metabolism in these proliferating tissues [46].

Liver is a key organ for the metabolism of free fatty acids (FFA) [47], and FFA are the source of TG synthesis in the liver [48]. The extracellular FFA pool in tumors undergoes continuous turnover, utilizing adipose tissue storage as a source [49]. It is reported that plasma FFA are increased in tumor bearing animals [50]. Increased plasma FFA is attributed to the hypermetabolic state in cancers [51]. Li, et al., [52] reported that proportions of plasma saturated and monounsaturated fatty acids in the HCC patients were significantly increased compared to the controls. Similar results were found in the patients with breast cancer suggesting that this could be a common finding in tumors [53]. It is believed that these FFA could be used as metabolic substrates by the tumor cells [54]. Hanai, et al. [55] evaluated seventeen hepatectomized cases (12 cases of HCC and 5 cases of metastatic liver cancer). In HCC tissues, the levels of alpha-linolenic acid (LA) and docosahexaenoic acid (DHA) were significantly less than those in the reference tissues those normal tissues surrounding tumors. Wood, et al., [56] analyzed total lipid extracts of liver tissue from 14 HCC patients and demonstrated that ratio of saturate $\mathrm{C} 18$ to unsaturated $\mathrm{C} 18$ in the tumor tissues were significantly and consistently lower than those corresponding non-tumor tissues. Palmitic acid was the most representative saturated FFA, while unsaturated FFA was represent, in decreasing order, by oleic, linoleic and arachidonic acids (AA) [57]. Available evidence [58] is consistent with the possibility that selective changes in the hepatocellular metabolism of long-chain fatty acids may contribute significantly to the activity of the extramitochondrial pathways, which may also contribute to liver injury and tumorigenesis. De Alaniz and Marra [59] demonstrated a significant contribution of the stearoyl-CoA desaturase system to the high levels of oleic acid (OA) present in hepatoma cells. Peroxisome proliferators are diverse group of chemicals which are regarded as rodent hepatocarcinogens and/or liver tumor promoters [60]. It has been demonstrated that peroxisome proliferators could increase hepatocyte proliferation and cause liver tumors in rodents, which is related to transcriptional activation of peroxisome proliferators-activated receptor (PPAR)- $\alpha$ regulated genes and the resulting excessive generation of $\mathrm{H}_{2} \mathrm{O}_{2}$. Evidence from mice lacking fatty acylCoA oxidase (AOX), PPAR- $\alpha$ and PPAR- $\alpha /$ AOX has confirmed the role of PPAR- $\alpha$ in the development of HCC [61-63]. As PPAR- $\gamma$ functions as a regulator of cell survival and growth in the HCC, PPAR- $\gamma$ therefore represents a putative molecular target for chemopreventive therapy or inhibition of HCC growth [64]. In addition, decreased expression of hepatic PPAR- $\alpha$ functions as one mechanism underlying the pathogenesis of HCV infection, PPAR- $\alpha$ may serve as a new therapeutic target in traditional treatment of HCV-induced liver injury [65].

\section{Plasma lipoprotein pattern in the patients with HCC}

Liver represents the main site of lipoprotein (a) $(\operatorname{Lp}(\mathrm{a}))$ synthesis [66-68]. Half-life of $\operatorname{Lp}(\mathrm{a})$ is about 3.3-3.9 days in human plasma [69], which is influenced in the early stage when liver function was impaired [66]. $\mathrm{Lp}(\mathrm{a})$ is synthesized and metabolized independently of other plasma lipoproteins, and Lp(a) level is not influenced by various dietary manipulations [70]. Motta, et al., [21] demonstrated that $\operatorname{Lp}(\mathrm{a})$ levels were significantly lower in the HCC patients $(5.7 \pm 2.08 \mathrm{mg} / \mathrm{dl})$ than in the controls $(16.78 \pm 16.24 \mathrm{mg} / \mathrm{dl})$. Higuchi, et al., [71] elucidated that influences of serum $\operatorname{Lp}(\mathrm{a})$ levels in some tumors could be characterized by the production and deliverance of cytokines. It has been reported that serum $\mathrm{Lp}(\mathrm{a})$ were significantly lower in the HCC patients [72,73]. However, Geiss, et al., [74] observed patients with acute hepatitis showed a marked increase in $\operatorname{Lp}(\mathrm{a})$ concentration, i.e., 7 $\mathrm{mg} / \mathrm{dL}$ in acute stage and $32 \mathrm{mg} / \mathrm{dL}$ in the convalescence of the disease. Basili, et al., reported that $\mathrm{Lp}(\mathrm{a})$ could also be increased in the patients suffered from HCC together with cirrhosis [75]. It has been demonstrated that $\operatorname{Lp}(\mathrm{a})$ together with ferritin and alpha-fetoprotein could be a sensitive and early marker to evaluate liver function [21]. As Lp(a) has positive correlation with the hepatic status, it has been suggested that $\operatorname{Lp}(\mathrm{a})$ could be considered as a index of liver function $[21,68,76]$.

The origin and fate of HDL are less well understood than other lipoproteins. HDL may be formed both in the intestine and in the liver. During lipolysis of TG-rich lipoproteins, HDL particles are also formed. ApoAI and apoAII are the major apolipoproteins of the HDL. Production rate of apoA-I is an important determinant of the variability of plasma HDL concentrations. It is influenced by many factors and apoA-I transcriptional regulation has an impact on plasma HDL concentrations. Nutritional inter- 
ventions such as, a switch from high-carbohydrate to a high-fat diet appears to exert their major effect on the production rate of apoA-I rather than on clearance $[20,77]$. HDL plays a key role in the reverse cholesterol transport pathway (RCTP) [24,78]. It has been demonstrated that HDL fraction offers a new approach to study liver diseases [19]. Ahaneku, et al., [36] analyzed HDL-fraction levels including HDL-cholesterol (HDL-C), HDL-phospholipids (HDL-PL) and the ratio of HDL-C/HDL-PL, in HCC patients and compared with the controls. They found that plasma HDL-C, HDL-PL and HDL-C/HDL-PL were significantly lower in HCC patients than those in the controls. Motta, et al., [21] studied 40 patients with HCC, and evaluated the LDL-C, HDL-C. In patients with HCC, LDL-C level was significantly lower than in the controls, but HDL-C did not show a statistically significant difference to the controls. Kanel, et al., [79] reported that patients with primary or metastatic liver cancer had strikingly decreased HDL-C. Ooi, et al., [22] suggested that HDL-C may be clinically useful to reflect the pathologic conditions, and can be used to evaluate the severity of liver diseases. In the metastatic liver cancer showed a lower HDLfraction level too, even lower than those in the HCC patients. Also, Fujii, et al., [23] found existence of HDL with an abnormal apoprotein composition or a more profound decrease of HDL3 than those of HDL2 in severe hepatocellular dysfunction of cholestasis. Cooper, et al., [19] observed that there was a rapid decreases of HDLcholesterol and LDL-cholesterol immediately after hepatic resection. Lipid profiles are different in the cirrhosis patients with or without HCC. In cirrhosis with HCC plasma phospholipid levels showed a significant negative correlation with total bilirubin and alanine aminotransferase. Total cholesterol (TC), phospholipids (PL) and the ratio of TC/PL were elevated, while HDL-C, HDL-PL, HDL-C/TC and HDL-PL/PL were normal. It is suggested that variations in the level of plasma lipids and lipoproteins may assist in describing the nature of these two forms of liver disease [36].

\section{Influence of HCC on apolipoproteins}

Liver is the main organ for the synthesis, storage, transportation and degradation of some apolipoproteins [20]. Each protein may be influenced by liver disease in a different way, and serum lipoprotein concentrations with faster turn-over are more reduced with respect to those with slower turn-over [80]. Serum concentrations of apoAI and A-II were significantly lower in the patients suffered from HCC $[23,24]$, but an increase in the proportion of proapoAI was found in patients with HCC [81]. The proportion of proapoAI showed a tendency toward increase under advanced liver damage because liver participates in the process of converting proapoAI to the mature apoAI. It is suggested that plasma apoAI could reflect the hepatocellular dysfunction $[2,19,82]$. The pattern of changes in the serum apoAI levels may be a good indicator of the hepatic protein synthetic ability during the perioperative period after hepatectomy [82]. ApoB in the liver was an important glycoprotein for transportation of VLDL and $\mathrm{LDL}$, in liver cells hyperexpression of HBx caused accommodation of MTG, HBx could increase the expression of beta-d-mannoside-,-N-acetylglucosaminyl transferase-III (GnT-III), and it could inhibit apoB secretion and enhanced the accumulation of intracellular triglyceride and cholesterol [83]. Ooi et al., [22] reported that slow alpha HDL appeared in the metastatic liver cancer in the early-middle stages, during slight bile stagnation, and accompanied by increases of apo E levels [84]. In our preliminary study we have observed that apolipoprotein $\mathrm{M}$ (apoM) mRNA levels were significantly lower in the HCC tissues than those in the normal hepatic tissues surrounding tumors (non-published data). Up to date there is no data reported concerning other apolipoproteins in relation to liver cancer.

\section{Using HDL and LDL as carriers for the water-insoluble anti-cancer drugs}

HDL transports cholesterol to liver cells, where they are recognized and taken up via specific receptors. Cholesteryl esters within HDL are selectively uptaken by hepatocytes via the scavenger receptor class B type I (SR-BI). An interesting feature of SR-BI is that the receptor selectively translocates HDL-cholesteryl esters from the lipoprotein particle to the cytosol of the liver parenchymal cells without a parallel uptake of the apolipoproteins and this property may allow for the delivery of its loaded drugs avoiding lysosomal degradation [85]. As HDL and LDL have high affinity and could be accumulated in tumor cells [86-88], they have been used as carriers for delivery of anti-tumor drugs into hepatoma cells to treat HCC [85,89-93]. Masquelier, et al., [94] investigated the possibilities to use LDL as a drug carrier to increase the selectivity of anti-tumor drugs in cancer chemotherapy. It has been demonstrated that both HDL and LDL may be used as endogenous targeting carriers into tumor cells, which have high lipoprotein-receptor activities, in animal models $[88,95]$. Anti-cancer drug-HDL complexes work as efficient drug delivery vehicles due to the ability of cancer cells to acquire HDL core components $[89,96]$. Complex of anti-cancer drugs with HDL and LDL does not influence characteristics of the drugs [92]. Lacko, et al., demonstrated that administration of anti-cancer drug-HDL complex may reduce toxic side-effects during the chemotherapy [89]. Lou, et al., reported in a cell culture system that cellular uptake of recombinant HDL-aclacinomycin (ACM) by the SMMC-7721 hepatoma cells was significantly higher than that of free ACM at the concentration range of $0.5-10 \mu \mathrm{g} / \mathrm{mL}(\mathrm{P}<0.01)$. Cytotoxicity of recombinant HDL-ACM to SMMC-7721 cells was significantly higher than that of free ACM at concentration range of less 
than $5 \mu \mathrm{g} / \mathrm{mL}(\mathrm{P}<0.01)$ and IC50 of recombinant HDLACM was lower than IC50 of free ACM $(1.68 \mathrm{nmol} / \mathrm{L}$ vs 3 $\mathrm{nmol} / \mathrm{L}$ ) [85]. Chu, et al., coupled doxorubicin (DOX) to human LDL to form a LDL-DOX complex. When the complexes injected into mice, LDL-DOX was more accumulated in liver than free DOX. In contrast, LDL-DOX was less accumulated in heart than free DOX [97]. It suggested that both HDL and LDL could be used as carriers to conjugate water-insoluble anti-cancer drugs leads to a higher accumulation of the drugs locally and specifically.

\section{Conclusion}

It is thus evident that liver plays a vital role in the production and catabolism of plasma lipoproteins and apolipoproteins. Plasma lipid profiles could be changed in HCC. It has been summarized in the Table 1 . Analysis of serum levels of lipids, lipoproteins and apolipoproteins in the patients suffered from HCC may reflect the condition of hepatic cellular impairment, and may also be used as an indicator to evaluate patient's prognosis. It is suggested that variations in the levels of plasma lipids and lipoproteins may assist in describing the nature of HCC with or without cirrhosis. The serum apoAI and Lp(a) levels may considered as the index of liver impairments under chronic or HCC. In addition, HDL and LDL had been used as a carrier for delivering chemotherapeutic drugs in HCC and other cancers.

\section{Abbreviations}

HDL, high density lipoprotein; VLDL, very low density lipoprotein; LDL, low density lipoprotein; HCC, hepatocellular carcinoma; Lp (a), lipoprotein (a), HBx, X protein of hepatitis B virus; GnT-III, beta-d-mannoside-,-Nacetylglucosaminyl transferase-III; apoB, Apolipoprotein B; Lp-X, lipoprotein X; FFA, free fatty acids; OA, oleic acid ; AA, arachidonic acid; DHA, docosahexaenoic acid; SR-BI, scavenger receptor class B type I.

\section{References}

I. Bell AW: Lipid metabolism in liver and selected tissues and in the whole body of ruminant animals. Prog Lipid Res 1979, 1 8(3): I I7-164.

2. Tietge UJ, Boker KH, Bahr MJ, Weinberg S, Pichlmayr R, Schmidt HH, Manns MP: Lipid parameters predicting liver function in patients with cirrhosis and after liver transplantation. Hepatogastroenterology 1998, 45(24):2255-2260.

3. Eisenberg S, Levy RI: Lipoprotein metabolism. Adv Lipid Res 1975, I 3: I-89.

4. Sherlock S: Alcoholic liver disease. Lancet 1995, 345(8944):227-229.

5. Parkin DM, Bray F, Ferlay J, Pisani P: Estimating the world cancer burden: Globocan 2000. Int J Cancer 200I, 94(2): I53-I56.

6. Harrison TJ, Chen JY, Zuckerman AJ: Hepatitis B and primary liver cancer. Cancer Treat Rev 1986, I3(I): I-I6.

7. Buendia MA: Mammalian hepatitis $B$ viruses and primary liver cancer. Semin Cancer Biol 1992, 3(5):309-320.

8. Rabe $C$, Cheng $B$, Caselmann WH: Molecular mechanisms of hepatitis B virus-associated liver cancer. Dig Dis 200I, I 9(4):279-287.

9. Shi J, Zhu L, Liu S, Xie WF: A meta-analysis of case-control studies on the combined effect of hepatitis $B$ and $C$ virus infec- tions in causing hepatocellular carcinoma in China. $\mathrm{Br} J$ Cancer 2005, 92(3):607-612.

10. Leung N: HBV and liver cancer. Med J Malaysia 2005, 60(Suppl B):63-66.

II. Cheng AS, Chan HL, Leung WK, To KF, Go MY, Chan JY, Liew CT, Sung J]: Expression of $\mathbf{H B x}$ and $\mathbf{C O X}-2$ in chronic hepatitis B, cirrhosis and hepatocellular carcinoma: implication of $\mathbf{H B x}$ in upregulation of COX-2. Mod Pathol 2004, I 7 ( I 0): I I 69- I I 79.

12. Zhang SW, Li LD, Lu FZ, Mu R, Sun XD, HuangP XM, Sun J, Zhou YC, $X D$ D: Mortality of primary liver cancer in China from 1990 through 1992(Chinese article). Chinese Journal of Oncology 1999, 2 I (4):245-249.

13. Nissen NN, Martin P: Hepatocellular carcinoma: the high-risk patient. J Clin Gastroenterol 2002, 35(5 Suppl 2):S79-85.

14. Zhiqiang G, Zhaohui D, Qinhuan W, Dexian C, Yunyun F, Hongtao L, lloeje UH: Cost of chronic hepatitis B infection in China. J Clin Gastroenterol 2004, 38(1 0 Suppl):SI75-178.

15. Miller JP: Dyslipoproteinaemia of liver disease. Baillieres Clin Endocrinol Metab I990, 4(4):807-832.

16. Colombo E, Mauri A, Scapaticci R, Bosoni AM, Bertella M, Nutta G: [Clinical significance of HDL-cholesterol variations in viral hepatitis]. Arch Sci Med (Torino) 1982, I39(2): I87-191.

17. Vergani C, Casciarri I, Cargnel A: Lipid disorders in acute viral hepatitis. Ric Clin Lab 1982, I2(I): I07-III.

18. Su TC, Lee YT, Cheng TJ, Chien HP, Wang JD: Chronic hepatitis B virus infection and dyslipidemia. J Formos Med Assoc 2004, I03(4):286-29I.

19. Cooper ME, Akdeniz A, Hardy KJ: Effects of liver transplantation and resection on lipid parameters: a longitudinal study. Aust N Z J Surg 1996, 66(I I):743-746.

20. Lewis GF, Rader DJ: New insights into the regulation of HDL metabolism and reverse cholesterol transport. Circ Res 2005, 96(12): $1221-1232$.

21. Motta M, Giugno I, Ruello P, Pistone G, Di Fazio I, Malaguarnera M: Lipoprotein (a) behaviour in patients with hepatocellular carcinoma. Minerva Med 2001, 92(5):301-305.

22. Ooi K, Shiraki K, Sakurai Y, Morishita Y, Nobori T: Clinical significance of abnormal lipoprotein patterns in liver diseases. Int J Mol Med 2005, I 5(4):655-660.

23. Fujii S, Koga S, Shono T, Yamamoto K, Ibayashi H: Serum apoprotein A-I and A-II levels in liver diseases and cholestasis. Clin Chim Acta 198I, I I 5(3):32I-33I.

24. Hachem H, Favre G, Raynal G, Blavy G, Canal P, Soula G: Serum apolipoproteins A-I, A-II and B in hepatic metastases. Comparison with other liver diseases: hepatomas and cirrhosis. J Clin Chem Clin Biochem 1986, 24(3): I6I-166.

25. Cicognani C, Malavolti M, Morselli-Labate AM, Zamboni L, Sama C, Barbara L: Serum lipid and lipoprotein patterns in patients with liver cirrhosis and chronic active hepatitis. Arch Intern Med 1997, I 57(7):792-796.

26. Alsabti EA: Serum lipids in hepatoma. Oncology 1979, 36(I):II-I4.

27. Michiel DF, Oppenheim J]: Cytokines as positive and negative regulators of tumor promotion and progression. Semin Cancer Biol 1992, 3(I):3-15.

28. Argiles JM, Lopez-Soriano FJ, Evans RD, Williamson DH: Interleukin- $I$ and lipid metabolism in the rat. Biochem J 1989 , 259(3):673-678.

29. Kwong LK, Ridinger DN, Bandhauer M, Ward JH, Samlowski WE, Iverius PH, Pritchard H, Wilson DE: Acute dyslipoproteinemia induced by interleukin-2: lecithin:cholesteryl acyltransferase, lipoprotein lipase, and hepatic lipase deficiencies. J Clin Endocrinol Metab 1997, 82(5): I572-I58I.

30. Navasa M, Gordon DA, Hariharan N, Jamil H, Shigenaga JK, Moser A Fiers W, Pollock A, Grunfeld C, Feingold KR: Regulation of microsomal triglyceride transfer protein mRNA expression by endotoxin and cytokines. J Lipid Res 1998, 39(6): I220-1230.

31. Casaschi A, Rubio BK, Maiyoh GK, Theriault AG: Inhibitory activity of diacylglycerol acyltransferase (DGAT) and microsomal triglyceride transfer protein (MTP) by the flavonoid, taxifolin, in HepG2 cells: potential role in the regulation of apolipoprotein B secretion. Atherosclerosis 2004, I 76(2):247-253.

32. Cheung DL, Hart PH, Vitti GF, Whitty GA, Hamilton JA: Contrasting effects of interferon-gamma and interleukin-4 on the interleukin-6 activity of stimulated human monocytes. Immunology 1990, 7 I(I):70-75. 
33. Patel PS, Shah MH, Jha FP, Raval GN, Rawal RM, Patel MM, Patel JB, Patel DD: Alterations in plasma lipid profile patterns in head and neck cancer and oral precancerous conditions. Indian J Cancer 2004, 4 I ( I):25-3I.

34. Krisans SK: Cell compartmentalization of cholesterol biosynthesis. Ann N Y Acad Sci 1996, 804:142-164.

35. Grunler J, Olsson JM, Dallner G: Estimation of dolichol and cholesterol synthesis in microsomes and peroxisomes isolated from rat liver. FEBS Lett 1995, 358(3):230-232.

36. Ahaneku JE, Taylor GO, Olubuyide IO, Agbedana EO: Abnormal lipid and lipoprotein patterns in liver cirrhosis with and without hepatocellular carcinoma. I Pak Med Assoc 1992 42(I I):260-263.

37. Li WX: [Serum cholesterol and cancer mortality: eleven-year prospective cohort study on more than nine thousand persons]. Zhonghua Liu Xing Bing Xue Za Zhi I993, I4(I):6-9.

38. Tomiki Y, Suda S, Tanaka M, Okuzawa A, Matsuda M, Ishibiki Y, Sakamoto K, Kamano T, Tsurumaru M, Watanabe Y: Reduced lowdensity-lipoprotein cholesterol causing low serum cholesterol levels in gastrointestinal cancer: a case control study. Exp Clin Cancer Res 2004, 23(2):233-240.

39. Siemianowicz K, Gminski J, Stajszczyk M, Wojakowski W, Goss M, Machalski M, Telega A, Brulinski K, Magiera-Molendowska H: Serum total cholesterol and triglycerides levels in patients with lung cancer. Int JMol Med 2000, 5(2):20I-205.

40. Siemianowicz K, Gminski J, Stajszczyk M, Wojakowski W, Goss M, Machalski M, Telega A, Brulinski K, Magiera-Molendowska H: Serum HDL cholesterol concentration in patients with squamous cell and small cell lung cancer. Int J Mol Med 2000, 6(3):307-3 I I.

4I. Simo Camps E, Orti Llaveria A, Sena Ferrer F, Contreras Barbeta E: [Blood cholesterol in patients with cancer]. An Med Interna 1998, I 5(7):363-366.

42. Eggens I, Ekstrom TJ, Aberg F: Studies on the biosynthesis of polyisoprenols, cholesterol and ubiquinone in highly differentiated human hepatomas. J Exp Pathol (Oxford) 1990, 7I(2):219-232.

43. Larking PW: Cancer and low levels of plasma cholesterol: the relevance of cholesterol precursors and products to incidence of cancer. Prev Med 1999, 29(5):383-390.

44. Eichholzer M, Stahelin HB, Gutzwiller F, Ludin E, Bernasconi F: Association of low plasma cholesterol with mortality for cancer at various sites in men: I7-y follow-up of the prospective Basel study. Am J Clin Nutr 2000, 7 I (2):569-574.

45. Panagiotakos DB, Pitsavos C, Polychronopoulos E, Chrysohoou C, Menotti A, Dontas A, Stefanadis C: Total cholesterol and body mass index in relation to $\mathbf{4 0}$-year cancer mortality (the Corfu cohort of the seven countries study). Cancer Epidemiol Biomarkers Prev 2005, | 4(7): |797-|80|

46. Dessi S, Batetta B, Pulisci D, Spano O, Anchisi C, Tessitore L, Costelli $\mathrm{P}$, Baccino FM, Aroasio E, Pani P: Cholesterol content in tumor tissues is inversely associated with high-density lipoprotein cholesterol in serum in patients with gastrointestinal cancer. Cancer 1994, 73(2):253-258.

47. Cowen $A E$, Campbell $C B$ : Bile salt metabolism. I. The physiology of bile salts. Aust N Z J Med 1977, 7(6):579-586.

48. Donnelly KL, Smith CI, Schwarzenberg S], Jessurun J, Boldt MD, Parks EJ: Sources of fatty acids stored in liver and secreted via lipoproteins in patients with nonalcoholic fatty liver disease. Clin Invest 2005, I I 5(5): I 343- I 35 I.

49. Mermier $\mathrm{P}$, Baker $\mathrm{N}$ : Flux of free fatty acids among host tissues, ascites fluid, and Ehrlich ascites carcinoma cells. I Lipid Res 1974, I 5(4):339-35I.

50. Frederick GL, Begg RW: A study of hyperlipemia in the tumorbearing rat. Cancer Res 1956, I 6(6):548-552

5I. Legaspi A, Jeevanandam M, Starnes HF Jr, Brennan MF: Whole body lipid and energy metabolism in the cancer patient. Metabolism 1987, 36(10):958-963.

52. Li YZZY, Wang CH: The analysis of serum free fatty acid spectrum in $\mathbf{3 3}$ patients with primary hepatocellular carcinoma. Journal of Dalian Medical University 1997, I 9(2): I34- I36.

53. Kumar K, Sachdanandam P, Arivazhagan R: Studies on the changes in plasma lipids and lipoproteins in patients with benign and malignant breast cancer. Biochem Int 1991, 23(3):58|-589.

54. Spector AA: The importance of free fatty acid in tumor nutrition. Cancer Res 1967, 27(9): I580-I586.
55. Hanai T, Hashimoto T, Nishiwaki K, Ono M, Akamo Y, Tanaka M, Mizuno I, Yura J: Comparison of prostanoids and their precursor fatty acids in human hepatocellular carcinoma and noncancerous reference tissues. I Surg Res 1993, 54(I):57-60.

56. Wood CB, Habib NA, Apostolov K, Thompson A, Barker W, Hershman $M$, Blumgart $\mathrm{LH}$ : Reduction in the stearic to oleic acid ratio in human malignant liver neoplasms. Eur J Surg Oncol 1985 I I (4):347-348

57. Greco AV, Mingrone G, Gasbarrini G: Free fatty acid analysis in ascitic fluid improves diagnosis in malignant abdominal tumors. Clin Chim Acta 1995, 239(I): I3-22.

58. Ockner RK, Kaikaus RM, Bass NM: Fatty-acid metabolism and the pathogenesis of hepatocellular carcinoma: review and hypothesis. Hepatology 1993, I8(3):669-676.

59. de Alaniz MJ, Marra CA: Role of delta 9 desaturase activity in the maintenance of high levels of monoenoic fatty acids in hepatoma cultured cells. Mol Cell Biochem 1994, I37(I):85-90.

60. Palut D: [Proliferation of peroxisomes and the hepatocarcinogenic process]. Rocz Panstw Zakl Hig I997, 48(I): I-I I

6I. James NH, Gill JH, Brindle R, Woodyatt NJ, Macdonald N, Rolfe M, Hasmall SC, Tugwood JD, Holden PR, Roberts RA: Peroxisome proliferator-activated receptor (PPAR) alpha-regulated growth responses and their importance to hepatocarcinogenesis. Toxicol Lett 1998, 102-103:91-96.

62. Peters JM, Rusyn I, Rose ML, Gonzalez FJ, Thurman RG: Peroxisome proliferator-activated receptor alpha is restricted to hepatic parenchymal cells, not Kupffer cells: implications for the mechanism of action of peroxisome proliferators in hepatocarcinogenesis. Carcinogenesis 2000, 2 I (4):823-826.

63. Yu S, Rao S, Reddy JK: Peroxisome proliferator-activated receptors, fatty acid oxidation, steatohepatitis and hepatocarcinogenesis. Curr Mol Med 2003, 3(6):56I-572.

64. Yu J, Qiao L, Zimmermann L, Ebert MP, Zhang H, Lin W, Rocken C, Malfertheiner P, Farrell GC: Troglitazone inhibits tumor growth in hepatocellular carcinoma in vitro and in vivo. Hepatology 2006, 43(I): I34-| 43

65. Dharancy S, Malapel M, Perlemuter G, Roskams T, Cheng Y, Dubuquoy L, Podevin P, Conti F, Canva V, Philippe D, et al.: Impaired expression of the peroxisome proliferator-activated receptor alpha during hepatitis $\mathbf{C}$ virus infection. Gastroenterology 2005, I 28(2):334-342.

66. Malaguarnera M, Trovato G, Restuccia S, Giugno I, Franze CM, Receputo G, Siciliano R, Motta M, Trovato BA: Treatment of nonresectable hepatocellular carcinoma: review of the literature and meta-analysis. Adv Ther 1994, I I(6):303-319.

67. Kraft HG, Menzel HJ, Hoppichler F, Vogel W, Utermann G: Changes of genetic apolipoprotein phenotypes caused by liver transplantation. Implications for apolipoprotein synthesis. I Clin Invest 1989, 83(I): |37-|42.

68. Malaguarnera M, Giugno I, Trovato BA, Panebianco MP, Restuccia N, Ruello P: Lipoprotein(a) in cirrhosis. A new index of liver functions? Curr Med Res Opin 1996, I3(8):479-485.

69. Krempler F, Kostner GM, Roscher A, Haslauer F, Bolzano K, Sandhofer F: Studies on the role of specific cell surface receptors in the removal of lipoprotein (a) in man. J Clin Invest 1983 7 I(5): |43|-|44|.

70. Albers J, Adolphson JL, Hazzard WR: Radioimmunoassay of human plasma Lp(a) lipoprotein. J Lipid Res 1977 I8(3):33|-338

7I. Higuchi K, Hospattankar AV, Law SW, Meglin N, Cortright J, Brewer $H B$ Jr: Human apolipoprotein B (apoB) mRNA: identification of two distinct apoB mRNAs, an mRNA with the apoB-100 sequence and an apoB mRNA containing a premature inframe translational stop codon, in both liver and intestine. Proc Natl Acad Sci USA 1988, 85(6): I772-1776.

72. Samonakis DN, Koutroubakis IE, Sfiridaki A, Malliaraki N, Antoniou P, Romanos ], Kouroumalis EA: Hypercoagulable states in patients with hepatocellular carcinoma. Dig Dis Sci 2004, 49(5):854-858.

73. Motta M, Pistone G, Franzone AM, Romeo MA, Di Mauro S, Giugno I, Ruello $P$, Malaguarnera M: Antibodies against ox-LDL serum levels in patients with hepatocellular carcinoma. Panminerva Med 2003, 45(I):69-73.

74. Geiss HC, Ritter MM, Richter WO, Schwandt P, Zachoval R: Low lipoprotein (a) levels during acute viral hepatitis. Hepatology 1996, 24(6): |334-1337. 
75. Basili S, Andreozzi P, Vieri M, Maurelli M, Cara D, Cordova C, Alessandri C: Lipoprotein (a) serum levels in patients with hepatocarcinoma. Clin Chim Acta 1997, 262(I-2):53-60.

76. Van Wersch JW: The behaviour of lipoprotein(a) in patients with various diseases. Scand J Clin Lab Invest I994, 54(7):559-562.

77. Eggerman TL, Hoeg JM, Meng MS, Tombragel A, Bojanovski D, Brewer HB Jr: Differential tissue-specific expression of human apoA-I and apoA-II. J Lipid Res I99I, 32(5):82I-828.

78. Genest JJ, McNamara JR, Ordovas JM, Martin-Munley S, Jenner JL, Millar J, Salem DN, Schaefer EJ: Effect of elective hospitalization on plasma lipoprotein cholesterol and apolipoproteins A-I, B and Lp(a). Am J Cardiol 1990, 65(9):677-679.

79. Kanel GC, Radvan G, Peters RL: High-density lipoprotein cholesterol and liver disease. Hepatology 1983, 3(3):343-348.

80. Phillips GB: The lipid composition of serum in patients with liver disease. J Clin Invest 1960, 39:1639-1650.

8I. Matsuura T, Koga S, Ibayashi H: Increased proportion of proapolipoprotein A-I in HDL from patients with liver cirrhosis and hepatitis. Gastroenterol Jpn 1988, 23(4):394-400.

82. Katsuramaki T, Hirata K, Kimura Y, Nagayama M, Meguro M, Kimura $\mathrm{H}$, Honma T, Furuhata T, Hideki U, Hata F, et al.: Changes in serum levels of apolipoprotein A-I as an indicator of protein metabolism after hepatectomy. Wound Repair Regen 2002, I 0(I):77-82.

83. Kang SK, Chung TW, Lee JY, Lee YC, Morton RE, Kim CH: The hepatitis $B$ virus $X$ protein inhibits secretion of apolipoprotein $B$ by enhancing the expression of $\mathbf{N}$ - acetylglucosaminyltransferase III. J Biol Chem 2004, 279(27):28I06-28II 2.

84. Hiraoka H, Yamashita S, Matsuzawa Y, Kubo M, Nozaki S, Sakai N, Hirano K, Kawata S, Tarui S: Decrease of hepatic triglyceride lipase levels and increase of cholesteryl ester transfer protein levels in patients with primary biliary cirrhosis: relationship to abnormalities in high-density lipoprotein. Hepatology 1993, I 8(I): 103-II0.

85. Lou B, Liao XL, Wu MP, Cheng PF, Yin CY, Fei Z: High-density lipoprotein as a potential carrier for delivery of a lipophilic antitumoral drug into hepatoma cells. World J Gastroenterol 2005 I I(7):954-959.

86. Tokui T, Takatori T, Shinozaki N, Ishigami M, Shiraishi A, Ikeda T, Tsuruo T: Delivery and cytotoxicity of RS- I 54 I in St-4 human gastric cancer cells in vitro by the low-density-lipoprotein pathway. Cancer Chemother Pharmacol 1995, 36(I): I-6.

87. Vitols S, Gahrton G, Peterson C: Significance of the low-density lipoprotein (LDL) receptor pathway for the in vitro accumulation of AD-32 incorporated into LDL in normal and leukemic white blood cells. Cancer Treat Rep 1984, 68(3):5 I5-520.

88. Versluis AJ, van Geel PJ, Oppelaar H, van Berkel TJ, Bijsterbosch MK: Receptor-mediated uptake of low-density lipoprotein by $B 16$ melanoma cells in vitro and in vivo in mice. $\mathrm{Br} /$ Cancer 1996 74(4):525-532.

89. Lacko AG, Nair M, Paranjape S, Johnso S, McConathy WJ: High density lipoprotein complexes as delivery vehicles for anticancer drugs. Anticancer Res 2002, 22(4):2045-2049.

90. Filipowska D, Filipowski T, Morelowska B, Kazanowska W, Laudanski $\mathrm{T}$, Lapinjoki S, Akerlund $M$, Breeze A: Treatment of cancer patients with a low-density-lipoprotein delivery vehicle containing a cytotoxic drug. Cancer Chemother Pharmacol 1992, 29(5):396-400.

91. Dubowchik GM, Firestone RA: Improved cytotoxicity of antitumor compounds deliverable by the LDL pathway. Bioconjug Chem 1995, 6(4):427-439.

92. Kader A, Pater A: Loading anticancer drugs into HDL as well as LDL has little affect on properties of complexes and enhances cytotoxicity to human carcinoma cells. J Control Release 2002, 80(I-3):29-44.

93. Pinheiro KV, Hungria VT, Ficker ES, Valduga CJ, Mesquita $\mathrm{CH}$, Maranhao RC: Plasma kinetics of a cholesterol-rich microemulsion (LDE) in patients with Hodgkin's and non-Hodgkin's lymphoma and a preliminary study on the toxicity of etoposide associated with LDE. Cancer Chemother Pharmacol 2005: I-7.

94. Masquelier M, Vitols S, Palsson M, Mars U, Larsson BS, Peterson CO: Low density lipoprotein as a carrier of cytostatics in cancer chemotherapy: study of stability of drug-carrier complexes in blood. J Drug Target 2000, 8(3): I55-164.

95. Tokui T, Kuroiwa C, Muramatsu S, Tokui Y, Sasagawa K, Ikeda T, Komai T: Plasma lipoproteins as targeting carriers to tumour tissues after administration of a lipophilic agent to mice. Biopharm Drug Dispos 1995, 16(2):91-103.

96. Wasan KM, Morton RE: Differences in lipoprotein concentration and composition modify the plasma distribution of free and liposomal annamycin. Pharm Res 1996, I3(3):462-468.

97. Chu AC, Tsang SY, Lo EH, Fung KP: Low density lipoprotein as a targeted carrier for doxorubicin in nude mice bearing human hepatoma HepG2 cells. Life Sci 200I, 70(5):591-60I.
Publish with Biomed Central and every scientist can read your work free of charge

"BioMed Central will be the most significant development for disseminating the results of biomedical research in our lifetime. "

Sir Paul Nurse, Cancer Research UK

Your research papers will be:

- available free of charge to the entire biomedical community

- peer reviewed and published immediately upon acceptance

- cited in PubMed and archived on PubMed Central

- yours - you keep the copyright 